\title{
Investigating English reading motivation across time
}

\author{
Parisa Daftarifard ${ }^{1}$, Servat Shirkhani ${ }^{2}$, Morvarid Lavasani ${ }^{1}$ \\ ${ }^{1}$ Department of Language and Literature, Science and Research Branch, Islamic Azad University, Tehran, Iran \\ ${ }^{2}$ Department of Foreign Languages, Khorram abad Branch, Islamic Azad University, Khorram abad, Iran
}

\section{Email address:}

pdaftaryfard@srbiau.ac.ir (P. Daftarifard), servatshirkhani@gmail.com (S. Shirkhani), ml.365@hotmail.com (M. Lavasani)

\section{To cite this article:}

Parisa Daftarifard, Servat Shirkhani, Morvarid Lavasani. Investigating English Reading Motivation across Time. International Journal of Language and Linguistics. Vol. 2, No. 5, 2014, pp. 305-309. doi: 10.11648/j.ijll.20140205.13

\begin{abstract}
This study aimed at investigating the possible dynamicity of reading motivation across time. To this end, the reading motivation questionnaire (Mori, 2002) was administered to about 101 BA students twice. The results indicated that reading motivation does not have a fixed construct. Different components of reading motivation might change in nature across time.
\end{abstract}

Keywords: Reading Motivation, Time, Reading Comprehension

\section{Introduction}

Any success and failure in second language acquisition (SLA) are somehow related to motivation (for example, Dornyei \& Csizer, 1998). As Arnold (1990) mentioned "very little can be accomplished if the learner is not at least minimally willing or motivated" (p. 25). It is probably because of this reason that a plethora of research has been conducted to investigate the possible constituents of motivation (Arnold \& Brown, 1999; Ehrman, 1995; Dornyei \& Skehan, 2003; Dornyei \& Cisizer, 1998); whether it is causatively and directly related to SLA (Brown, 2007; Ellis, 1994); or whether it is indirectly related to second language learning, through influencing other affective and cognitive factors of learner language (Arnold \& Brown, 1999).

Recently, it has been argued that reading motivation is vastly domain or task specific (Mori, 2002). Dornyei and Skehan (2003), and Shoaib and Dörnyei (2005) hold the idea that reading motivation is not a static construct and may change across time and setting. They endorsed the importance of time as an indispensable variable in studying motivation in educational contexts. Considering this view to be correct, there may be a different pattern underlying the components of motivation when the setting (place and time) changes (Dörnyei \& Skehan, 2003). Dörnyei and Skehan (2003) believed that "ignoring time in motivation can result in a situation where two theories are equally valid and yet contradict one another-simply because they refer to different phases of the motivation process" (p.618).
This is especially in line with the new view towards SLA as a multidisciplinary branch of study (Ellis, 2009).

To many researchers (Clement \& Kruidenier, 1985; Dornyei, 1990, 2000; Mori, 2002) motivation is a multifaceted construct. As far as the setting is concerned, Mori (2004) asserted that the EFL reading motivation has a different componential structure from first language reading motivation. It was hypothesized that foreign language reading motivation, although different in some respects from L1 reading motivation, would be a multidimensional construct, and, to a certain degree, independent of general motivational constructs. She further concluded that foreign language reading motivation closely resembles more general forms of motivation as laid out in expectancy-value theory. Although more research is needed to verify this point, the results of her research confirm the multidimensionality of reading motivation, and suggest that it is rash to label certain students as either motivated or not motivated to read. This line of research is also essential to explore the relationship between reading motivation and reading behavior. (p. internet page)

Taking all these into account, it would be intriguing to examine whether time specificity would change the structure of reading motivation as asserted by Dornyei and Skehan (2003). Motivation is claimed to have an unfixed, changeable, and malleable nature. Time has been mentioned as a determinant in studying motivation (Ellis, 1994; Cohen \& Dornyei, 2002; Dornyei \& Skehan, 2003). This is especially important when we take into account the dynamic as well as classroom-tied nature of motivation. To 
date, much research on motivation has focused on the interaction of learners' motivation with their language abilities (Ellis, 1994), and the relationship between motivation and extensive L2 reading (Takase, 2007), or other constitutive factors of motivation (Clement, 1980, cited in Dornyei \& Skehan, 2003). However, to our knowledge, there is not much research done to examine the pattern of reading motivation across time. Dornyei and Skehan (2003), referring to the dynamic nature of motivation, suggested that researchers have used time as an organizing principle. They noted that time might be the intervening variable that may lead to incommensurable result.

\section{Motivation to Read in Second Language}

Most research, as was mentioned earlier, has focused on learners' motivation and its interaction with their language abilities (Gardner, 1980 as cited in Ellis, 1994), perseverance in pursuing language learning (Clement, Smythe, \& Gardner, 1978 cited in Ellis, 1994), or other constitutive factors of motivation (Deci \& Ryan, 2000; Dornyei \& Skehan, 2003). Recently, motivation is studied in relation to specific task or skill. For example, Mori (2000 - 2002) has studied motivation in relation to reading comprehension.

Mori (2002) modified the original version of L1 reading motivation questionnaire to observe the English Foreign Language (EFL) setting. Wigfield and Guthrie $(1995,1997)$ classified L1 reading motivation in terms of three components of competence and reading efficacy (including reading efficacy, reading challenge, and reading work avoidance), achievement values and goals (including intrinsic motivation and extrinsic motivation), and social aspects of reading (including social reasons for reading, and reading compliance). However, through factor analysis and by including some of the items from Gardner's socioeducational model of motivation, Mori (2002) came up with different factor clusters of reading motivation as (1) Intrinsic Value of Reading, (2) Extrinsic Utility Value of Reading, (3) Importance of Reading and (4) Reading Efficacy. Intrinsic motivation refers to reading curiosity, involvement, avoidance, and challenge. Extrinsic Utility means "perceived usefulness as explained in expectancy value theory" (p. 8). In addition, Importance of Reading includes items such as explaining the importance of reading in coping with internationalization, following general education, broadening my view, developing me into a more knowledgeable person, and unimportance of learning reading. Finally, Reading Efficacy refers to reader's self evaluation about his or her reading ability.

Although different scholars have worked on motivation, scarce research has been conducted with a specific attention to the moderating role of time. It is believed that time can be an indicative factor in configuration of the construct of motivation (Dornyei \& Skehan, 2003). This led scholars to believe that motivation cannot be explained in a simple model, firstly proposed by Gardner and Lambert (1972 as cited in Arnold \& Brown, 1999). Instead, reading motivation has been claimed to be a multifaceted construct (Clement \& Kruidenier, 1985; Dornyei, 1990, 2000; Mori, 2002). This means that motivation is a more malleable, process and task based construct. In this way, scholars believe in taking into account the process of motivation rather than its static nature as a product.

\section{The Present Study}

This study attempts to investigate possible changes in English learners' motivation if the setting and time change. Recently, there is a call for research to investigate the possible dynamic nature of motivation ( Dornyei \& Skehan, 2003). They noted that time might be the intervening variable that leads to incommensurable result. To this end, the present study attempts to answer the following questions:

1. Is there any relationship between subcategories of motivation across time?

2. Is there any difference between subcategories of motivation across time?

\section{Methodology}

\subsection{Participants}

The total of 101 (64 male, 37 female) Iranian university students majoring in humanities at the Islamic Azad University participated in this study. All the students formed intact groups. $90 \%$ of the students rated themselves as elementary students. Moreover $92 \%$ of the students reported that they did not attend any Private English class outside university.

\subsection{Instruments}

Mori's redefined motivation for reading questionnaire (RMRQ) (2002) was used in this study. This questionnaire includes four components of Intrinsic Value of Reading (11 items), Extrinsic Utility Value of Reading (7 items), Importance of Reading (5 items), and Reading Efficacy (4 items) (Mori, 2002, 2004). The questionnaire was distributed to the students twice: one time at the beginning of the semester and another time before their final exam. This is because the purpose of this research is to see whether the factor of time would affect the pattern of reading motivation. The respondents were asked to rate each question on a five-point scale based on their perceived importance with 1 indicating as not important to 5 indicating as very important.

\subsection{Procedure}

To learn about the learners' degree of motivation and the 
construct of motivation, Reading Motivation (Mori, 2002) was administered twice to BA students studying various majors at the university level. First the questionnaire was translated to Persian to ensure the learners' response validity. Then, the questionnaire was administered twice. The first time the questionnaire was given to learners to investigate their possible baseline motivational factors. The second time which was near the end of the course after their reading class, the questionnaire was given to investigate the possible changes of their motivational state over time. The data before any further analysis were reversed in some of its items $(21,17,27,30,28,23$, and 8). The reason was that these items had negative content in stem.

The test in each time enjoys a fairly acceptable reliability indices of $\alpha=0.745$ for the first administration and $\alpha=$ 0.861 for the second time of administration.

Table 1 shows the descriptive statistics of the Reading Motivation questionnaire in each time. As is shown in this table, the mean scores of each sub category in pretest and posttest are between 3.1 and 3.8. Moreover, post Intrinsic has the highest standard error of measurement $(\mathrm{SE}=1.195)$ It means that the respondents function differently as far as their Extrinsic Reading Motivation is concerned in their posttest.

Table 1. Descriptive Statistics for different Parts of Reading Motivation across Time

\begin{tabular}{llllll}
\hline & & Mean & N & Std. Deviation & Std. Error Mean \\
\hline \multirow{2}{*}{ Pair 1 } & Pre-intrinsic & 3.1332 & 101 & .76553 & .07617 \\
& Post-intrinsic & 3.1557 & 101 & 1.09245 & .10870 \\
Pair 2 & Pre-extrinsic & 3.2249 & 101 & .68701 & .06836 \\
& Post-extrinsic & 3.0905 & 101 & .65768 & .06544 \\
Pair 3 & Pre-importance & 3.8416 & 101 & .70218 & .06987 \\
& Post-importance & 3.5782 & 101 & .78989 & .07860 \\
Pair 4 & Pre-efficacy & 3.4950 & 101 & .96759 & .09628 \\
\end{tabular}

\section{Data Analysis and Results}

To answer the questions of this study, different statistical methods were performed. Correlation coefficients between reading motivation subcategories across time was estimated. To answer the second question of this study as if there is any difference between subcategories of motivation across time, four different matched T-test was run.

\subsection{Correlational Study: Reading Motivation Subcategories across Time}

To search for possible changes in the relationship among Reading Motivation subcategories across time, Pearson correlation coefficient was run for each subcategory in both pretest and posttest. The result is shown in Table 2 .

Table 2. Correlational Indices among Subcategories of Motivation across Time

\begin{tabular}{|c|c|c|c|c|c|c|c|c|}
\hline & Pre-intrinsic & Pre-extrinsic & Pre-importance & Pre-efficacy & Post-intrinsic & Post-extrinsic & Post-importance & Post-efficacy \\
\hline Pre-intrinsic & 1 & & & & & & & \\
\hline Pre-extrinsic & $\begin{array}{l}.660^{* *} \\
.000\end{array}$ & 1 & & & & & & \\
\hline $\begin{array}{l}\text { Pre- } \\
\text { importance }\end{array}$ & $\begin{array}{l}.520^{* *} \\
.000\end{array}$ & $\begin{array}{l}.551^{* *} \\
.000\end{array}$ & 1 & & & & & \\
\hline Pre-efficacy & $\begin{array}{l}.504^{* *} \\
.000\end{array}$ & $\begin{array}{l}.334^{* *} \\
.001\end{array}$ & $\begin{array}{l}.167 \\
.094\end{array}$ & 1 & & & & \\
\hline Post-intrinsic & $\begin{array}{l}.513^{* *} \\
.000\end{array}$ & $\begin{array}{l}.468^{* *} \\
.000\end{array}$ & $\begin{array}{l}.316^{* *} \\
.001\end{array}$ & $\begin{array}{l}.352^{* *} \\
.000\end{array}$ & 1 & & & \\
\hline Post-extrinsic & $\begin{array}{l}.289^{* *} \\
.003\end{array}$ & $\begin{array}{l}.613^{* *} \\
.000\end{array}$ & $\begin{array}{l}.367^{* *} \\
.000\end{array}$ & $\begin{array}{l}.314^{* *} \\
.001\end{array}$ & $\begin{array}{l}.512^{* *} \\
.000\end{array}$ & 1 & & \\
\hline $\begin{array}{l}\text { Post- } \\
\text { importance }\end{array}$ & $\begin{array}{l}.352^{* *} \\
.000\end{array}$ & $\begin{array}{l}.533^{* *} \\
.000\end{array}$ & $\begin{array}{l}.468^{* *} \\
.000\end{array}$ & $\begin{array}{l}.318^{* *} \\
.001\end{array}$ & $\begin{array}{l}.477^{* *} \\
.000\end{array}$ & $\begin{array}{l}.760^{* *} \\
.000\end{array}$ & 1 & \\
\hline Post-efficacy & $\begin{array}{l}.331^{* *} \\
.001\end{array}$ & $\begin{array}{l}.323^{* *} \\
.001\end{array}$ & $\begin{array}{l}.061 \\
.542\end{array}$ & $\begin{array}{l}.616^{* *} \\
.000\end{array}$ & $\begin{array}{l}.260^{* *} \\
.009\end{array}$ & $\begin{array}{l}.312^{* *} \\
.002\end{array}$ & $\begin{array}{l}.287^{* *} \\
.004\end{array}$ & 1 \\
\hline
\end{tabular}

**. Correlation is significant at the 0.01 level (2-tailed).

As is shown in this table, all subcategories of Reading Motivation are correlated with each other significantly except for Reading Efficacy and Importance of Reading in pretest $(\mathrm{r}=0.167, \mathrm{P}=\mathrm{NS})$. The interesting point is that these two subcategories turned out to be significantly correlated in Posttest $(\mathrm{r}=0.287, \mathrm{p}<0.05)$. Also, Importance of Reading in pretest and Reading Efficacy in posttest are not significantly correlated, whereas Importance of 
Reading in posttest and Reading Efficacy in posttest are significantly correlated $(\mathrm{r}=0.28, \mathrm{P}<0.05)$. The result might indicate that importance of reading has changed from pretest to posttest.

Moreover, as table 2 shows, the correlation coefficients between Reading efficacy and other subcategories of Reading Motivation has changed from pretest to posttest. For example, Reading Efficacy in pretest is correlated fairly high with Intrinsic Motivation in pretest $(r=0.504$, $\mathrm{P}<0.005)$, whereas the correlation between Reading Efficacy and Intrinsic Motivation in posttest has changed to a lower score $(\mathrm{r}=0.260, \mathrm{P}<0.05)$. The same is true for Extrinsic Motivation and Reading Efficacy.

To compare the significance of differences, Fisher $r$ to $Z$ transformation was used. The results showed that the $\mathrm{Z}=$ 2.02 is significant $(P=0.02)$ for Intrinsic Motivation and Reading Efficacy in pretest and posttest, whereas $\mathrm{Z}$ is not significant $(Z=0.17, P=N S)$ for Extrinsic Motivation and Reading Efficacy. This means that learners in the present study have changed significantly from pretest to posttest as far as their state is concerned with their Intrinsic Motivation and Reading Efficacy.

\subsection{T-Test: Difference between Reading Motivation Subcategories over Time}

To investigate the possible different functions between Reading Motivation subcategories across time, Four Matched T-test were run. The results are shown in Table 3. As is indicated in this table two pairs of Extrinsic motivation and Reading Importance from four pairs showed significant difference between pretest and posttest ( $\mathrm{t}$ Extrinsic $=2.282, \mathrm{p}=0.025 ; \mathrm{t}$ Reading Importance $=$ 3.424, $\mathrm{P}=0.001)$. This shows that learners' state has changed from pretest to posttest as far as these two categories are concerned. To locate the difference, we can refer to table 1 to compare the means for each pair. Table 1 shows that learners are less extrinsically motivated in posttest $(\mathrm{M}=3.09, \mathrm{SE}=0.06)$. Also, the Importance of reading in posttest has increased significantly $(\mathrm{Mpos}=3.57$, $\mathrm{SE}=0.07)$. This is a positive point of this study. According to Dornyei and Skehan (2003) intrinsic motivation is a positive motivation and is more permanent than extrinsic motivation which is temporary and situation bound.

Table 3. Matched T-Test Between Subcategories of Reading Motivation across Time

\begin{tabular}{llllllll}
\hline & & Mean & Std. Deviation & Std. Error Mean & t & df & Sig. (2-tailed) \\
\hline Pair 1 & Pre-intrinsic - post-intrinsic & -.022 & .95972 & .09550 & -.236 & 100 & .814 \\
Pair 2 & Pre-extrinsic - Post-extrinsic & .134 & .59172 & .05888 & 2.282 & 100 & .025 \\
Pair 3 & Pre-importance - Post-importance & .263 & .77301 & .07692 & 3.424 & 100 & .001 \\
Pair 4 & Pre-efficacy - Post-efficacy & .089 & .78628 & .07824 & 1.139 & 100 & .257 \\
\hline
\end{tabular}

\section{Discussion}

The theory of Motivation has changed over time from a simple construct to more social and psychological based model. This causes many scholars to view the construct as more dynamic and situation based. Such changes especially led scholars to develop task and domain specific questionnaires to study motivation in relation to different skills like reading (Mori, 2002). Also, the dynamic view to motivation, as adopted and suggested by Dornyei and Skehan (2003) and later examined by Shoaib and Dörnyei (2005), endorsed the importance of time as the important variable in studying motivation within educational contexts If this view is correct, there may be a different pattern underlying the components of motivation when the setting (place and time) will change.

The results of this study indicated that the construct of Reading motivation function differently over time. Learners were less extrinsically motivated in posttest, whereas learners' conception of Importance of reading in posttest has increased significantly. Moreover, Importance of Reading in pretest and Reading Efficacy in posttest are not significantly correlated, whereas Importance of Reading in posttest and Reading Efficacy in posttest are significantly correlated. Ehrman (1995) classified motivation into two types of extrinsic and intrinsic. Extrinsic motivation means doing a job for internal satisfaction while extrinsic motivation "represents the desire for some kind of external benefits" (p. 138). Instrument motivation is very similar to extrinsic motivation; however, integrative motivation can be both intrinsic and extrinsic. According to Brown (1994 cited in Ehrman, 1995) instrumental motivation can be intrinsic too. many factors (Deci \& Ryan, 2000) such as threats, Surveillance, evaluation, and deadlines will shift learners' intrinsic motivation to more extrinsically derived motivation due to "the perceived locus of causality" (p.234). Such factors undermine autonomy, decrease creativity, and results in poor problem solving. Therefore, "perceived autonomy is required for the motivation to be intrinsic" (p.235). Also, autonomy is related to the sense of secure and relatedness (Ryan \& La Guardia, 2000 cited in Deci \& Ryan, 2000). Students who believe that their teachers are warm and caring showed greater intrinsic motivation (Ryan, Stiller, \& Lynch, 1994 cited in Deci \& Ryan, 2000).

As learning another language is not simply learning a new subject-it involves learning a new culture, a new communication code, and a new idea-motivation in language is different from motivation in other school subject (Cohen \& Dornyei, 2002). Therefore, it is interwoven with socio-cultural factors. Gardner's socio- 
educational model explains second language learning in classroom setting. Accordingly, the social and cultural surrounding (milieu) "in which learners grow up determines their beliefs about language and culture" (Ellis, 1994, p.236). These variables include motivation, aptitude. The result indicates the importance of classroom as an indicative factor in changing English learners' motivational state either negatively or positively. As Dornyei and Skehan (2003) stated the effort should be made to increase intrinsic motivation which is a positive motivation. The result of this research calls for investigation for possible classroom bound factors that might negatively or positively affect reading motivation.

\section{References}

[1] Arnold, J. (1990). Affect in language learning. Cambridge: CUP.

[2] Arnold, J., \& Brown, H. D. (1999). A map of the terrain. In J. Arnold (Ed.), Affect in language learning (pp.1-25). Cambridge: CUP.

[3] Brown, H. D. (2007). Principles of language learning and teaching. London: Longman.

[4] Clement, R., \& Kruidenier, B. (1985). Aptitude, attitude and motivation in second language proficiency: A test of Clement's model. Journal of Language and Social Psychology, 4, 21-37.

[5] Cohen, A. D., \& Dornyei, Z. (2002). Focus on the language learner: Motivation, styles and strategies. In N. Schmitt (Ed.), An Introduction to Applied Linguistics (pp. 170-190). Arnold: NY.

[6] Deci, E. L., \& Ryan, R. M. (2000). The "what" and "why" of goal pursuits: Human needs and the self-determination of behavior. Psychological Inquiry, 11(4), 227-268.

[7] Dornyei, Z. (1990). Conceptualizing motivation in foreign language learning. Language Learning, 40, 46-78.
[8] Dornyei, Z. (2000). Motivation in action: Towards a process-oriented conceptualization of student motivation. British Journal of Educational Psychology, 70, 519-538.

[9] Dörnyei, Z., \& Csizér, K. (1998). Ten commandments for motivating language learners: results of an empirical study. Language Teaching Research, 2, 203-229.

[10] Dornyei, A., \& Skehan, P. (2003). Individual differences in second language learning. In C. Doughty \& M. H. Long (eds.), The handbook of second language acquisition (pp. 589-630). New York: Blackwell.

[11] Ehrman, M. (1995). Ego boundaries and tolerance of ambiguity in second language learning. In J. Arnold (Ed.), Affect in language learning (pp.68-86). Cambridge: CUP.

[12] Ellis, R. (1994). The Study of Second Language Acquisition. Oxford: OUP.

[13] Mori, S. (2004). Significant motivational predictors of the amount of reading by EFL learners in Japan. RELC, 35, 6381.

[14] Mori, S. (2002). Redefining motivation to read in a foreign language. Reading in a Foreign Language, 14( 2), internet page downloaded from http://nflrc.hawaii.edu/rfl/october2002

[15] Shoaib, A., Dörnyei. Z. (2005). Affect in life-long learning: Exploring L2 motivation as a dynamic process. In P. Benson \& D. Nunan (Eds.), Learners' stories: Difference and diversity in language learning (pp. 22-41). Cambridge: Cambridge University Press.

[16] Takase, A. (2007). Japanese high school students' motivation for extensive L2 reading. Reading in a Foreign Language, 19, 1-16.

[17] Wigfield, A. \& Guthrie, J. T. (1995). Dimensions of children's motivations for reading: An initial study (Research Rep. No. 34). Athens, GA: National Reading Research Center.

[18] Wigfield, A. \& Guthrie J. T. (1997). Relations of children's motivation for reading to the amount and breadth of their reading. Journal of Educational Psychology, 89, 420-432. 